WANG, J., X. Y. KANG and D. L. LI (2012a): High temperature-induced triploid production during embryo sac development in Populus. Silvae Genet 61: 85-93.

WANG, J., D. LI and X. KANG (2012b): Induction of unreduced megaspores with high temperature during megasporogenesis in Populus. Ann Forest Sci 69: 59-67.

Wu, H., S. Zheng, Y. He, G. Yan, Y. Bi and Y. ZHU (2007): Diploid female gametes induced by colchicine in Oriental lilies. Sci Hortic 114(1): 50-53.

XI, X., L. Guo, W. Xu, J. Zhang and B. Li (2014): Megasporogenesis, megagametogenesis, and induction of $2 \mathrm{n}$ eggs with colchicine in poplar section Aigeiros. Scand J Forest Res 29(6): 527-536.

YAo, X., J. Deng and H. HuAng (2012): Genetic diversity in Eucommia ulmoides (Eucommiaceae), an endangered traditional Chinese medicinal plant. Conserv Genet 13(6): 1499-1507.
You, H., T. JIA, J. TIAN, J. WANG and X. KANG (2014): Characteristics of in vitro pollen germination and microfilament distribution of pollen tubes of Eucommia ulmoides Oliv. Acta Bot Boreal-Occident Sin 34(3): 495-501.

Zhang, Z. Y., F. L. Li, Z. T. ZHU and X. Y. KANG (1997): Doubling technology of pollen chromosome of Populus tomentosa and its hybrid. J Beijing For Univ (English Ed.) 6(2): 9-20.

Zноu, Z. X. (1993): Eucommia ulmoides of China. Guizhou Science and Technology Press, Guiyang.

ZHU, Z., X. KANG and Z. ZHANG (1997): Advances in the triploid breeding program of Populus tomentosa in China. J Beijing For Univ (English Ed.) 6(2): $1-8$.

The English in this document has been checked by at least two professional editors, both native speakers of English. For a certificate, please see: http://www.textcheck.com/certificate/QZ2V8L

\title{
Individual, fruit, and annual variation in correlated mating in a Genipa americana population
}

\author{
By R. O. Manoel ${ }^{1)}$, M. L. M. Freitas ${ }^{2)}$, E. Furlani Júniro ${ }^{1)}$, \\ P. F. AlveS ${ }^{1)}$, M. L. T. Moraes ${ }^{1)}$ and A. M. SebBenN ${ }^{2), *}$
}

(Received 16 ${ }^{\text {th }}$ May 2015)

\begin{abstract}
In this paper, we use six microsatellite loci to examine a spatially isolated population of Genipa americana in relation to mating system variation at the level of individual and among and within fruits, over two reproductive events. For our analysis, we sampled hierarchically among and within fruits open-pollinated seeds collected from 13 seed trees during the reproductive event in 2010 and 12 seed trees in 2011. The rate of mating among relatives $\left(1-t_{s}\right)$ was

1) Ilha Solteira School of Engineering/UNESP, CP 31, Ilha Solteira, São Paulo 15385-000, Brazil.

2) Forestry Institute of São Paulo, Rua do Horto 931, CP 1322, São Paulo, São Paulo 01059-970, Brazil.

*) Corresponding author: A. M. SEBbenn. Forestry Institute of São Paulo, Rua do Horto 931, C.P. 1322, 02377-000, São Paulo, SP, Brazil.

Telephone: +55 1934351681 .

E-Mail: alexandresebbenn@yahoo.com.br
\end{abstract}

significantly greater than zero and different between the investigated reproductive events, indicating that some seeds are inbred. The estimate of fixation index $\left(F_{o}\right)$ was significantly higher than zero for seeds from both reproductive events $\left(2010: F_{o}=0.258 ; 2011: F_{o}=0.294\right)$, confirming that seeds present inbreeding, probably originated from mating among full-sibs. The multilocus paternity correlation within fruits $\left(r_{p(w)}\right)$ and among fruits $\left(r_{p(a)}\right)$ varied among seed trees and reproductive events. The $r_{p(w)}$ was significantly higher than $r_{p(a)}$ in both reproductive events, suggesting that it is more likely to find full-sibs within fruits (2010: 36.4\%; 2011: 72.4\%), than among fruits (2010: 18.9\%; 2011: $12.8 \%$ ). Due to the presence of inbreeding, mating among relatives and correlated mating, the within families coancestry coefficient $(\Theta)$ was higher and the variance effective size $\left(N_{e}\right)$ lower than expected in openpollinated families from panmictic populations 
$\left(\Theta=0.125, N_{e}=4\right)$. In practical terms for conservation programs, our results show the need to collect seeds from at least 60 seed trees to retain progeny arrays with a total effective size of 150 .

Key words: Inbreeding; Mating system; Microsatellite markers; Tropical tree species.

\section{Introduction}

Tropical forests contain some of the greatest diversity of tree species in the world, sequestering vast amounts of carbon, and playing a vital role in maintaining the planet's biodiversity. However, as a result of indiscriminate harvesting, the advancement of agriculture, and urban sprawl, tropical forest ecosystems are among the most devastated in the world. Within the state of São Paulo, Brazil, the process of native forest conversion triggered by human activities, has resulted in the forest ecosystem being reduced to small patches or isolated remnants of less than 100 ha (RIBEIRo et al., 2009). Only $13.9 \%$ of the natural vegetation currently remains in the state (RIBEIRo et al., 2009). This increase in disturbed native forests has been a major challenge for conservationists. Quantifying the impact of habitat degradation on forest remnants may help not only to evaluate the genetic and ecological consequences brought about by these changes, but it may also underscore the conservation value of the remaining fragments by estimating the future repercussions of tropical deforestation. Such assessments also aid in the formulation of effective conservation strategies and the sustainable management of genetic resources of species that inhabit degraded landscapes (WHITE et al., 1999). For this purpose, studies have investigated the negative impacts of forest fragmentation (KAMM et al., 2010; SEBBENN et al., 2011; MANOEL et al., 2012; QuesADA et al., 2013). Molecular genetic studies have became part of such analyses as they provide a detailed understanding of the consequences of forest fragmentation on remaining populations, allowing the establishment of well-informed strategies for in situ and ex situ conservation, as well as seed collection strategies for environmental recovery (SEBBENN et al., 2011).

The mating system of a species determines the level and the distribution of genetic diversity within and among populations, as well as inbreeding and effective population size within the populations (GoodwILLIE et al., 2005;
SEBbEnN et al., 2011). Furthermore, it is responsible for gene transfer from one generation to another, which may occur by random mating, correlated mating, selfing, or combinations thereof (DEGEN and SeBbenn, 2014). However, factors such as spatial isolation of trees (FUCHS et al., 2003), variation in flowering phenology (ODdOU-Muratorio et al., 2006) and population density (MURAWSKI and HAMRICK, 1991) may affect the reproductive patterns of plants. Although tree species are usually the result of outcrossing, with an outcrossing rate above 80\% (DEGEN and SEBBENN, 2014), flexible mating systems have been observed, resulting in high rates of selfing (WARD et al., 2005; BREED et al., 2012). The occurrence of selfing may be problematic for low density populations, typical of many tropical tree species, when low or no pollen flow occurs between spatially isolated individuals across a landscape (ECKERT et al., 2009; BREED et al., 2012). While selfing is impossible for dioecious species, inbreeding can occur through mating among relatives.

Genipa americana L. (Rubiaceae) is a dioecious, semi-deciduous, slow growing tree species, found throughout tropical America (LORENZI, 2002; DURIGAN and NoGUEIRA, 1990). Adult trees can reach 8 to $14 \mathrm{~m}$ tall and $60 \mathrm{~cm}$ in diameter at breast height (DBH) (LORENZI, 2002). Pollination occurs by bees and wasps and trees produce fruit annually, with large quantities of viable seeds, which are dispersed mainly by barochory, hydrochory, and monkeys (CARVAlHo, 2003). In general, populations of G. americana have low densities $(<1$ individ$\mathrm{ual} / \mathrm{ha}$ ) and the trees have been highly recommended for mixed planting in swampy and degraded areas (DURIGAN and NoGUEIRA, 1990). However, even when population density is higher than 1 individual per hectare, only a limited $(<200)$ number of individuals of the species are found in small and isolated forest fragments. As such, it is necessary to adopt strategies for ex situ and in situ genetic conservation of remaining populations.

In this study, we investigate the inbreeding and mating system, hierarchically within and among fruits from two reproductive events of a G. americana population, to better define seed sampling strategies for ex situ conservation, tree breeding, and environmental reforestation programs. Specifically, we explore the following questions: i) Is there variation in rate of mating among relatives and correlated mating among 
different hierarchical units? ii) How many seed trees are required for seed collection within the population to ensure a founding population with an effective size of 150 ?

\section{Materials and methods}

\section{Study site and sampling}

The study was conducted in the 'Mata da Figueira' $\left(22^{\circ} 16^{\prime} \mathrm{S}\right.$ and $47^{\circ} 11^{\prime} \mathrm{W}$, average altitude $600 \mathrm{~m}$ ), a small forest fragment (7.2 ha) of riparian semideciduous, mesophytic plateau forest. The fragment is part of the Mogi Guaçú Experimental Station of the Forestry Institute of São Paulo. The riparian area is part of the Mogiana watershed, where the Mogiana River runs for approximately $660 \mathrm{~m}$. Currently, the forest is surrounded by agriculture (sugarcane, Eucalyptus) and pasture. The soils are classified as flood plain types LVa and LE (hydromorphic), subject to periodic flooding. The climate is the Cwa type, characterized as humid and mesothermal, according to the KöPPEN classification (KöPPEN, 1948); the mean monthly temperature varies from 14.30 to $24.65^{\circ} \mathrm{C}$. The dry season extends from May to August, and the rainy season ( $86.2 \%$ of precipitation) from September to April.

Open-pollinated seeds were collected from 13 seed trees in 2010 and 12 seed trees in 2011. For DNA analysis, we sampled cambial tissue from seed trees. We collected a fruit at each of the cardinal points (North $=\mathrm{N}$; South $=\mathrm{S}$; East $=\mathrm{E}$; West $=\mathrm{W}$ ) from each tree, totalling four fruits per tree. All fruits were collected to ensure that the cardinal points were sampled correctly. Seeds were germinated separately by fruit and seed tree and 15-25 seeds per fruit were obtained for the genetic study.

\section{Microsatellite genotyping}

The genetic material (DNA) was extracted from the cambial tissue of all 25 seed trees using the method described by NovaEs et al. (2009). From germinated seeds, DNA was extracted from leaf tissue using the method described by Doyle and Doyle (1987). Six loci were used for the study: Gam01, Gam02, Gam06, Gam11, Gam24, and Gam41. Locusspecific primers were developed by MANOEL et al. (2014) and they present Mendelian segregation and they are not linked (MANOEL et al., 2015). Details of amplification can be found in MANOEL et al. (2014).

\section{Analysis of the mating system}

We carried out our analysis of the mating system using the MLTR program (RITLAND, 2002). The analyses were estimated at the seed tree and population level. We used the maximum likelihood Expectation-Maximization (EM) numerical method at the seed tree level and the Newton-Rapson method at the population level. We estimated the pollen and ovules gene frequencies, multilocus $\left(t_{m}\right)$ and single locus outcrossing rate $\left(t_{s}\right)$, outcrossing rate between related individuals $\left(t_{m}-t_{s}\right)$, and multilocus paternity correlation $\left(r_{p}\right)$. However, as G. americana is dioecious, the effective rate of mating among relatives was estimated as: $1-t_{s}$. As our sample was hierarchical within and among fruits, the multilocus paternity correlation was also estimated within $\left(r_{p(w)}\right)$ and among fruits $\left(r_{p(a)}\right)$. The $95 \%$ confidence interval $(95 \% \mathrm{CI})$ was estimated using the $2.5 \%$ of minimum percentile estimated values, and $97.5 \%$ of maximum percentile estimated values, obtained by 1000 bootstrap re-sampling. The re-sampling units were families in the population analysis and individuals within families in the individual analysis. These indexes were used to estimate other demographic and genetic indexes, including: effective number of pollen donors $\left(N_{e p}=1 / r_{p}\right.$, RITLAND, 1989), and average coancestry coefficient $(\Theta)$ within families, calculated as: $\Theta=0.125\left(1+F_{m}\right)\left(1+r_{p}\right)$, where $F_{m}$ is the inbreeding coefficient of the seed trees (Moraes et al., 2012), estimated for each seed tree using SPAGEDI program (HARDY and VEKEMANS, 2002). The variance effective size within families $\left(N_{e}\right)$ was estimated following CocKERHAM (1969) as: $\left.N_{e}=0.5 /\{\Theta[n-1) / n]+\left(1+F_{o}\right) / 2 n\right\}$, where, $n$ is the sample size (assumed as 1000) and $F_{o}$ is the average family inbreeding coefficient, estimated from fixation index. Because each plant within family received at least one of the maternal alleles, $F_{o}$ the estimated for families can be biased due to overestimation of gene frequencies of maternal alleles in comparison to true gene frequencies of these alleles in the parental population. Overestimation of the gene frequencies result in overestimated expected heterozygosity under Hardy-Weinberg equilibrium $\left(H_{e}=1-\sum_{i=1}^{k} p_{i}^{2}\right.$, where $p_{i}^{2}$ is the frequency of the allele $i$, NEI, 1977), because alleles with high frequency contributed more for the estimate of $H_{e}$ than alleles with low frequency. Thus, as $F_{o}$ for family was calculated by $F_{o}=1-\left(H_{o} / H_{e}\right)$ (NEI, 1977), and overestimation in $H_{e}$ decreases the estimate of $F_{o}$, we corrected the gene frequencies, using the gene frequen- 
cies of the pollen parents, calculated using MLTR (RITLAND, 2002). In contrast, the observed heterozygosity $\left(H_{o}\right)$ was calculated for family with FSTAT program (GOUDET, 2002). For estimate $\Theta$ and $N_{e}$, negative values of $F_{m}$ and $F_{o}$ were assumed to be zero, because these indexes represent probability measures in the formulae for $\Theta$ and $N_{e}$, derivatives for the inbreeding coefficient (with a range from 0 to 1 ), and not for the correlation measures (the fixation index range from -1 to 1 ). Negative $F_{m}$ and $F_{o}$ can result in lower $\Theta$ and higher $N_{e}$ than the minimum expected values for open-pollinated families $\left(\Theta=0.125, N_{e}=4\right.$, respectively).
We calculate the number of seed trees for seed collection based on the objective of retaining an effective reference size of 150 in the total sample (progeny arrays), as $m=N_{e(\text { reference })} / N_{e} \quad$ (SEBBENN, 2006). This estimate is based on two suppositions: i) the seed trees are not related; and ii) the seed trees do not receive an overlapping pollen pool (each seed tree mated with a different set of pollen donors). Thus, $m$ is the minimum number of seed trees needed for seed collection. The harmonic mean of $m$ was estimated for 2010, 2011 and all families by:

Table 1. - Mating system in two reproductive events (years 2010 and 2011) of a Genipa americana population.

\begin{tabular}{|c|c|c|}
\hline Index & $\begin{array}{l}\text { Seeds from } 2010 \\
\text { mean }(95 \% \mathrm{CI})\end{array}$ & $\begin{array}{l}\text { Seeds from } 2011 \\
\text { mean }(95 \% \mathrm{CI})\end{array}$ \\
\hline Number of seed trees: $n_{s t}$ & 13 & 12 \\
\hline Number of secds: $n$ & 936 & 967 \\
\hline Fixation index of seed trees: $F_{m}$ & $-0.053(-0.110-0.004)$ & $0.106(0.013-0.199)^{*}$ \\
\hline Fixation index of seed: $F_{o}$ & $0.258(0.184-0.333)^{*}$ & $0.294(0.213-0.374)^{*}$ \\
\hline Multilocus outcrossing rate: $t_{m}$ & $0.867(0.843-0.889)$ & $0.946(0.932-0.961)$ \\
\hline Single locus outcrossing rate: $t_{s}$ & $0.629(0.608-0.651)$ & $0.581(0.564-0.595)$ \\
\hline Outcrossings rate among relatives: $t_{m i}-t_{s}$ & $0.238(0.235-0.238)$ & $0.368(0.365-0.366)$ \\
\hline Lffective outcrossing rate among relatives: $1-t_{s}$ & $0.371(0.3490 .392)$ & $0.419(0.4050 .436)$ \\
\hline Correlation of paternity within and among fruits: $r_{n}$ & $0.412(0.373-0.443)$ & $0.747(0.715-0.771)$ \\
\hline Correlation of paternity within fruits: $r_{r(w)}$ & $0.553(0.504-0.599)$ & $0.842(0.807-0.871)$ \\
\hline Cortelation of paternity almong fruits: $r_{p(a)}$ & $0.364(0.324-0.395)$ & $0.714(0.679-0.742)$ \\
\hline Difference $r_{p(n)} \quad r_{p(n)}$ & $0.189(0.146-0.237)$ & $0.128(0.099-0.163)$ \\
\hline Effective number of pollen donors (among and within): $N_{e \psi}$ & $2.4(2.3-2.7)$ & $1.3(1.3-1.4)$ \\
\hline Fifective number of pollen donors (within): $N_{\text {wit wy }}$ & $1.8(1.7-2.0)$ & $1.2(1.1-1.2)$ \\
\hline Effective number of pollen donors (among): $N_{a p i t}$ & $2.7(2.5-3.1)$ & $1.4(1.3-1.5)$ \\
\hline Hixation index maternal trees: $F_{m}$ & $-0.200(-0.200-0.200)$ & $0.106(0.013-0.199)$ \\
\hline Coancestry among and within families: $\Theta$ & $0.183(0.176-0.191)$ & $0.242(0.217-0.265)$ \\
\hline Variance effective size (among and within): $N_{\mathrm{c}}$ & $2.74(2.68-2.73)$ & $2.07(1.88-2.30)$ \\
\hline Number of sced trees for seed collection: $m$ & $53(52-54)$ & $73(65-80)$ \\
\hline
\end{tabular}

${ }^{*} P<0.05$. (95\% CI is the confidence interval at $95 \%$ of probability). The $F_{o}$ values were estimated using the observed heterozygosity $\left(H_{o}\right)$ of seeds expected heterozygosity $\left(H_{e}\right)$ estimated from gene frequencies of pollen parents. 


$$
m=\frac{1}{\left(\frac{1}{n_{f}}\right) \sum_{n f=1}^{n_{f}} \frac{1}{m_{i}}},
$$

where $n_{f}$ is the number of families and $m_{i}$ is the number of seed trees required to retain the effective size of 150 in seed tree $i$. The lower $95 \%$ CI of the coancestry within families $(\Theta)$ was estimated using the lower 95\% CI of and $F_{m}$ and $r_{p}$, and the upper CI using the higher $95 \% \mathrm{CI}$ of $F_{m}$ and $r_{p}$. The lower $95 \% \mathrm{CI}$ of $N_{e}$ was estimated using the upper values of $\Theta$ and $F_{o}$, and the upper, using the lower values of $\Theta$ and $F_{o}$. The lower $95 \%$ CI of $m$ was estimated using the upper value of $N_{e}$, and the upper $95 \%$ CI using the lower values of $N_{e}$. For each families we also estimated the number of alleles over all loci $(k)$ and mean allelic richness $(R)$, using the FSTAT program (GOUDET, 2002).

\section{Statistical analyses}

To investigate whether the sample size $(n)$ and the indexes $H_{o}, F_{o}, N_{e p}$ and $N_{e}$ were related, the coefficient of determination from Spearman ranking correlation was estimated among individual families, using the SAS program (SAS, 1999).

\section{Results}

\section{Mating system at the population level}

The average fixation index of the seed trees $\left(F_{m}\right)$ for seeds collected in 2010 was significantly less than zero, but higher than zero for the 2011 seed trees (Table 1). The average fixation index $\left(F_{o}\right)$ for seeds collected in 2010 and 2011 was significantly higher than zero (2010: $F_{o}=0.258$; 2011: $F_{o}=00.294$ ), suggesting inbreeding. The estimate of the population multilocus $\left(t_{m}\right)$ and single-locus $\left(t_{s}\right)$ outcrossing rates were significantly less than unity (1.0) in both reproductive events, suggesting mating among related individuals (Table 1). The differences $t_{m}-t_{s}$ and $1-t_{s}$ were significantly greater than zero, confirming the occurrence of mating among relatives. The total paternity correlation within and among fruits $\left(r_{p}\right)$, within fruits $\left(r_{p(w)}\right)$, and among fruits $\left(r_{p(a)}\right)$ was significantly greater than zero in both reproductive events, indicating correlated mating. However, the correlation within fruits $\left(r_{p(w)}\right)$ was significantly higher than among fruits $\left(r_{p(a)}\right)$, especially in 2010, where the difference $r_{p(w)}-r_{p(a)}$ was greatest $(0.189)$. This result indicates that the effective number of pollen donors was lower within fruits $\left(N_{e p(w)}\right)$ than among fruits $\left(N_{e p(a)}\right)$. The correlations $r_{p}, r_{p(w)}$, and $r_{p(a)}$ were also significantly lower and the results for $N_{e p}, N_{e p(w)}$, and $N_{e p(a)}$ significantly higher in the 2010 reproductive event than in 2011, indicating temporal variation in correlated mating. The coancestry coefficient within families $(\Theta)$ was significantly higher and the variance effective size $\left(N_{e}\right)$ significant lower in the 2011 reproductive event compared to 2010. Consequently, our results for the number of seed trees required for seed collection $(m)$ was higher for the reproductive event in 2011 (53) than in 2010 (73). The harmonic mean of $m$ was also lower in 2010 (54) than in 2011 (68), and for all familie is 60 seed trees.

\section{Genetic diversity and mating system} at the family level

For the seed trees from which seeds were collected in 2010 , the $F_{m}$ ranged from -0.33 to 0.31 and in 2011 from -0.47 to 0.84 (Table 2). In the 2010 reproductive event, the total number of alleles $(k)$ ranged among families from 20 to 28 , the observed heterozygosity $\left(H_{o}\right)$ from 0.39 to 0.60 , and the fixation index within family $\left(F_{o}\right)$ from 0.10 to 0.40 ; in the 2011 event, $F_{m}$ ranged from -0.47 to $0.84, k$ from 18 to $27, H_{o}$ from 0.43 to 0.65 , and $F_{o}$ from 0.15 to 0.44 . In 2010, the outcrossing rate was significantly different from unity (1.0) in 12 of the 13 families and in 7 of the 12 families in 2011. The difference $1-t_{s}$ ranged among the 2010 families from 0.10 to 0.50 and for the 2011 families from 0.16 to 0.50 , indicating mating among related trees occurred in many seed trees. The total paternity correlation within and among fruits $\left(r_{p(m)}\right)$ ranged in 2010 from 0.16 to 0.53 and in 2011 from 0.41 to 0.84 . The paternity correlation within fruit was higher $\left(r_{p(w)}\right)$ than among fruits $\left(r_{p(a)}\right)$ for all seed trees in both reproductive events, demonstrating that there is a greater probability of finding full-sib individuals within fruits. Therefore, the effective number of pollen donors within fruits $\left(N_{e p(w)}\right)$ was lower than among fruits $\left(N_{e p(a)}\right)$ in both reproductive events. Consequently, the average within families coancestry coefficient $(\Theta)$ ranged from 0.146 to 0.412 and the variance effective size $\left(N_{e}\right)$ from 1.20 to 3.16 . 
Table 2. - Genetic and mating system indexes in families of the reproductive events in 2010 and 2011.

\begin{tabular}{|c|c|c|c|c|c|c|c|c|c|c|c|c|c|c|c|}
\hline Seed tree & $F_{m}$ & $n$ & $k$ & $H_{* t}$ & $F_{0}$ & $t_{m} \pm \mathrm{SD}$ & $1-t_{s}$ & $r_{n} \pm \mathrm{SD}$ & $r_{\mu(w)} \pm \mathrm{SD}$ & $r_{p(u)} \pm \mathrm{SD}$ & $N_{p ?}$ & $N_{p(w)}$ & $N_{t^{\prime} \mid\{[a]}$ & $\theta$ & $N_{r}$ \\
\hline $2010-21$ & 0.03 & 30 & 20 & 0.48 & 0.25 & $0.85 \pm 0.05^{*}$ & 0.29 & $0.23 \pm 0.02$ & $0.96 \pm 0.08$ & $0.16 \pm 0.03$ & 4.4 & 1.0 & 6.3 & 0.158 & 2.88 \\
\hline $2010-25$ & -0.23 & 80 & 23 & 0.49 & 0.24 & $0.83 \pm 0.05^{*}$ & 0.16 & $0.39 \pm 0.05$ & $0.67 \pm 0.09$ & $0.31 \pm 0.04$ & 2.5 & 1.5 & 3.2 & 0.174 & 2.70 \\
\hline $2010-37$ & -0.24 & 79 & 22 & 0.44 & 0.31 & $0.88 \pm 0.04 *$ & 0.22 & $0.24 \pm 0.03$ & $0.34 \pm 0.06$ & $0.22 \pm 0.02$ & 4.1 & 3.0 & 4.6 & 0.156 & 2.98 \\
\hline $2010-39$ & -0.33 & 79 & 24 & 0.46 & 0.29 & $0.94 \pm 0.03 *$ & 0.15 & $0.19 \pm 0.03$ & $0.27 \pm 0.05$ & $0.17 \pm 0.02$ & 5.2 & 3.7 & 6.0 & 0.149 & 3.10 \\
\hline $2010-79$ & 0.08 & 80 & 28 & 0.51 & 0.20 & $0.94 \pm 0.03^{*}$ & 0.22 & $0.40 \pm 0.06$ & $0.60 \pm 0.08$ & $0.32 \pm 0.05$ & 2.5 & 1.7 & 3.1 & 0.189 & 2.51 \\
\hline $2010-107$ & 0.14 & 79 & 26 & 0.60 & 0.22 & $0.94 \pm 0.04^{*}$ & 0.23 & $0.29 \pm 0.03$ & $0.59 \pm 0.07$ & $0.21 \pm 0.03$ & 3.4 & 1.7 & 4.7 & 0.185 & 2.56 \\
\hline $2010-128$ & 0.03 & 80 & 24 & 0.44 & 0.31 & $0.88 \pm 0.04^{*}$ & 0.16 & $0.27 \pm 0.05$ & $0.46 \pm 0.10$ & $0.22 \pm 0.04$ & 3.8 & 2.2 & 4.6 & 0.164 & 2.84 \\
\hline $2010-129$ & -0.14 & 77 & 23 & 0.42 & 0.34 & $0.64 \pm 0.05^{k}$ & 0.50 & $0.53 \pm 0.04$ & $0.96 \pm 0.06$ & $0.44 \pm 0.04$ & 1.9 & 1.0 & 2.3 & 0.192 & 2.46 \\
\hline $2010-131$ & 0.31 & 68 & 25 & 0.57 & 0.10 & $0.91 \pm 0.04^{*}$ & 0.25 & $0.30 \pm 0.04$ & $0.56 \pm 0.09$ & $0.23 \pm 0.03$ & 3.3 & 1.8 & 4.3 & 0.214 & 2.24 \\
\hline $2010-145$ & -0.07 & 65 & 23 & 0.44 & 0.31 & & 0.26 & $0.16 \pm 0.02$ & $0.46 \pm 0.12$ & $0.13 \pm 0.02$ & 6.1 & 2.2 & 7.5 & & 3.16 \\
\hline $2010-147$ & -0.27 & 80 & 27 & 0.56 & 0.12 & $0.93 \pm 0.03^{k}$ & 0.16 & $0.35 \pm 0.05$ & $0.60 \pm 0.09$ & $0.28 \pm 0.04$ & 2.8 & 1.7 & 3.6 & 0.169 & 2.79 \\
\hline $2010-158$ & -0.23 & 61 & 22 & 0.39 & 0.40 & $0.82 \pm 0.05^{*}$ & 0.22 & $0.19 \pm 0.02$ & $0.80 \pm 0.10$ & $0.10 \pm 0.02$ & 5.2 & 1.2 & 9.7 & 0.149 & 3.07 \\
\hline $2010-161$ & 0.22 & 78 & 24 & 0.46 & 0.29 & $0.99 \pm 0.01$ & 0.10 & $0.24 \pm 0.04$ & $0.35 \pm 0.07$ & $0.20 \pm 0.033$ & 4.2 & 2.8 & 5.0 & 0.189 & 2.50 \\
\hline $2011-1$ & 0.84 & 80 & 18 & 0.43 & 0.44 & & & $0.79 \pm 0.03$ & $0.94 \pm 0.05$ & & 1.3 & 1.1 & & & 1.20 \\
\hline $2011-8$ & 0.20 & 80 & 24 & 0.49 & 0.36 & $0.85 \pm 0.04^{*}$ & 0.50 & $0.84 \pm 0.01$ & $1,00 \pm 0.02$ & $0.75 \pm 0.02$ & 1.2 & 1,0 & 1.3 & 0.275 & 1.78 \\
\hline 201$]-9$ & -0.35 & 79 & 25 & 0.59 & 0.23 & $0.98 \pm 0.02$ & 0.20 & $0.46 \pm 0.04$ & $0.64 \pm 0.07$ & $0.39 \pm 0.04$ & 2.2 & 1.6 & 2.6 & 0.182 & 2.60 \\
\hline $2011-14$ & 0.19 & 80 & 22 & 0.63 & 0.18 & $1.00 \pm 0.00$ & 0.21 & $0.52 \pm 0.04$ & $0.77 \pm 0.06$ & $0.43 \pm 0.04$ & 1.9 & 1.3 & 2.3 & 0.191 & 2.56 \\
\hline $2011-16$ & 0.16 & 79 & 20 & 0.65 & 0.15 & $1.00 \pm 0.00$ & 0.23 & $0.59 \pm 0.03$ & $0.74 \pm 0.05$ & $0.51 \pm 0.03$ & 1.7 & 1.3 & 1.9 & 0.199 & 2.46 \\
\hline $2011-24$ & -0.47 & 78 & 27 & 0.61 & 0.21 & $0.83 \pm 0.04 *$ & 0.27 & $0.47 \pm 0.04$ & $0.73 \pm 0.08$ & $0.37 \pm 0.04$ & 2.1 & 1.4 & 2.6 & 0.184 & 2.65 \\
\hline $2011-26$ & -0.15 & 80 & 24 & 0.58 & 0.24 & $0.95 \pm 0.03^{*}$ & 0.29 & $0.48 \pm 0.05$ & $0.76 \pm 0.07$ & $0.39 \pm 0.05$ & 2.1 & 1.3 & 2.5 & 0.185 & 2.62 \\
\hline $2011-28$ & -0.09 & 79 & 27 & 0.59 & 0.23 & $0.99 \pm 0.01$ & 0.16 & $0.41 \pm 0.04$ & $0.60 \pm 0.06$ & $0.35 \pm 0.044$ & 2.4 & 1.7 & 2.9 & 0.177 & 2.74 \\
\hline $2011-29$ & 0.31 & 80 & 23 & 0.43 & 0.44 & $0.86 \pm 0.04^{*}$ & 0.46 & $0.54 \pm 0.04$ & $0.78 \pm 0.06$ & $0.45 \pm 0.04$ & 1.8 & 1.3 & 2.2 & 0.252 & 1.94 \\
\hline $2011-35$ & 0.16 & 80 & 23 & 0.52 & 0.33 & $0.96 \pm 0.02^{*}$ & 0.36 & $0.69 \pm 0.04$ & $0.84 \pm 0.05$ & $0.61 \pm 0.04$ & 1.4 & 1.2 & 1.6 & 0.245 & 2.00 \\
\hline $2011-38$ & 0.01 & 80 & 23 & 0.54 & 0.30 & $0.93 \pm 0.03 *$ & 0.38 & $0.74 \pm 0.013$ & $1.00+0.02$ & $0.64 \pm 0.03$ & 1.3 & 1.0 & 1.6 & 0.219 & 2.23 \\
\hline $2011-85$ & 0.30 & 79 & 21 & 0.45 & 0.41 & $0.99 \pm 0.01$ & 0.49 & $0.80 \pm 0.03$ & $1.00 \pm 0.00$ & $0.68 \pm 0.04$ & 1.2 & 1.0 & 1.5 & 0.294 & 1.67 \\
\hline
\end{tabular}

$\pm \mathrm{SD}$ is the standard deviation; ${ }^{*} P<0.05 ; n$ is sample size within families; $F_{m}$ and $F_{o}$ are the fixation index of seed trees and within families, respectively; $k$ is the total number of alleles; $H_{o}$ is the observed heterozygosity; $t_{m}$ is the multilocus outcrossing rate; $1-t_{s}$ is the effective rate of mating among relatives; $r_{p(a)}, r_{p(w)}$, and $r_{p(a)}$ are the correlations of paternity within and among fruits, within fruits, and between fruits, respectively; $N_{e p}, N_{e p(w)}$, and $N_{e p(a)}$ are the effective numbers of pollen donors within and among fruits, within fruits, and among fruits, respectively; $\Theta$ and $N_{e}$ are the coancestry coefficients and variance effective size within families, respectively.

Table 3. - Coefficient of determination $\left(\mathrm{R}^{2}\right.$, degrees of freedom $=42$ ) between the sample size $(n)$, total number of alleles $(k)$, observed heterozygosity $\left(H_{o}\right)$, fixation index $\left(F_{o}\right)$, effective number of pollen donors $\left(N_{e p}\right)$, and variance effective size $\left(N_{e}\right)$ within families.

\begin{tabular}{|c|c|c|c|c|c|}
\hline & $k$ & $I_{t}$ & $F_{11}$ & $N_{t^{\prime}}$ & $N_{r}$ \\
\hline$n$ & 0.092 & 0.045 & $-(0.0099$ & -0.248 & -0.106 \\
\hline$k$ & - & 0.135 & -0.019 & 0.003 & 0.105 \\
\hline$H_{11}$ & - & - & -0.191 & -0.136 & 0.001 \\
\hline$N_{p p}$ & - & - & . & - & $0.592^{*}$ \\
\hline
\end{tabular}

\section{Correlation between indexes of genetic diversity and mating system}

We found no association between the sample size of individual families $(n)$, total number of alleles $(k)$, observed heterozygosity $\left(H_{o}\right)$, fixation index $\left(F_{o}\right)$, effective number of pollen donors $\left(N_{e p}\right)$, and variance effective size $\left(N_{e}\right)$ (Table 3). Significant positive association was only detected between $N_{e p}$ and $N_{e}$, indicating that an increase in the effective number of pollen donors increases the within families effective size.

\section{Discussion}

Our analysis of mating system of a G. americana population showed variation in the rate of mating among relatives and correlated mating within and among fruits between the two evaluated reproductive events and the seed trees. Thus, the sampled open-pollinated seeds present inbreeding and relatedness higher than expected in panmitic or random mating populations. Deviations from random mating have implications for seed collection within populations to genetic conservation and breeding, implicating the necessity of collect seed from many seed trees, as we will discuss bellow.

\section{Mating among relatives}

At the population level, and for the individual analysis of 25 seed trees, estimates of the outcrossing rate $\left(t_{m}\right)$ were significantly lower than 
unity (1.0) in the two studied reproductive events and 18 seed trees. This result is unexpected for a dioecious species and the apparent selfing in this case indicates mating among relatives (MorAes et al., 2012). In both reproductive events, the rate of mating among relatives at the population level $\left(1-t_{s}\right.$, minimum $\left.37.1 \%\right)$ and at the families level (maximum 50\%) was high. Consequently, the mating is not random in this population and the families produced in both seasons contained inbred individuals, as confirmed by the estimate of fixation index (2010: $\left.\quad F_{o}=0.258 ; 2011: \quad F_{o}=0.294\right)$. Mating among relatives $\left(1-t_{s}=0.383\right)$ and inbreeding $\left(F_{o}=0.302\right)$ was also detected in the same population in a previous study based on isoenzymes loci (SEBBENN et al., 1998), thus reinforcing our findings. Mating among relatives is an indicative of intrapopulational spatial genetic structure (SGS), with typically originates from seed dispersal near to the seed trees (HARDY et al., 2006; TARAZI et al., 2013; Degen and SEbBenn, 2014). The seed dispersal distance depends on dispersal vectors. In the case of $G$. americana, seed dispersal occurs first by barochory and secondarily through hydrochory and zoochory and primates (VIEIRA et al., 1996). Because the population persist in a small forest fragment (7.2 ha), it is possible that regeneration occurs in close proximity to the seed trees.

Inbreeding resulting from mating among relatives is equal to the coancestry coefficient between the parents (LINDGREN et al., 1997). Comparisons of the levels of inbreeding detected in the studied generations, the results indicate that seeds were the result of mating between individuals with coancestry levels close to minimum expected for not inbred full-sibs $(\Theta=0.25)$.

\section{Correlated mating}

The results at the population and individual levels indicate substantial and different levels of correlated mating between the reproductive events and individuals within and among fruits $\left(r_{p}\right)$, within fruits $\left(r_{p(w)}\right)$ and among fruits $\left(r_{p(a)}\right)$. Correlated mating was higher in the 2011 reproductive event, resulting in a lower effective number of pollen donors within and among fruits $\left(N_{e p}\right)$, within fruits $\left(N_{e p(w)}\right)$, and among fruits $\left(N_{e p(a)}\right)$, than in 2010 . The probability of sampling two seeds from one fruit being fullsibs was $55.3 \%$ in the 2010 reproductive event and $84.2 \%$ in 2011 . The higher $r_{p(w)}$ than $r_{p(a)}$ suggests that a maximum of two pollen donors fertilized each fruit and three pollen donors fertilized the trees, indicating also genetic drift. Thus, limited number of pollen donors contrasts with the number of potential pollen donors, or male trees. The occurrence of genetic drift is likely due to individual variation in the flowering phenology of male and female trees, especially in 2011. In tree species pollinated by animals, such as $G$. americana, pollinator vectors can deposit many pollen grains of a recently visited tree, resulting in seeds within fruits that are full-sibs (SAMPSON, 1998). Similar results have been reported for other tree species such as Eucalyptus rameliana (SAMPSON, 1998), Pachira quinata (QUESADA et al., 2001), Magnolia stellata (TAMAKI et al., 2009), Theobroma cacao (SILvA et al., 2011) and Tabebuia roseo-alba (FEREs et al., 2012). Our results support the idea that for animal-pollinated tree species with multiple-seed fruits, individual fruits are pollinated by a limited number of pollen donors (DEGEN and SEBBENN, 2014).

\section{Number of seed trees for seed collection}

Due to in some seed trees $\left(F_{m}\right)$ and within families $\left(F_{o}\right)$, as well as genetic drift resulting from mating among relatives and correlated mating, the within families coancestry coefficient $(\Theta)$ was higher and the variance effective size $\left(N_{e}\right)$ lower than expected for openpollinated families from panmictic populations $\left(\Theta=0.125, N_{e}=4\right)$, particularly during the 2011 reproductive event. Furthermore, a significant positive association between $N_{e p}$ and $N_{e}$, demonstrates that an increase in the effective number of pollen donors correlated positively with the effective size within progenies. Inbreeding increases the frequency of identical by descent alleles within families, thus decreasing the variance effective size. Therefore, the estimated harmonic mean number of seed trees for seed collection $(m)$, to retain progeny arrays with a total effective size of 150 , was higher in the 2011 reproductive event (68 trees) than in 2010 (54 trees). The estimated harmonic mean of $m$ for both seasons is higher than thosr estimated for other tropical tree species, such as 56 for Hymenaea courbaril (LACERDA et al., 2008), and about 50 for Theobroma cacao (SILVA et al., 2011). Our results underscore the need to consider intervention strategies that promote genetic connectivity through gene flow among 
populations. Over time, this population will be not only become spatially isolated, but also genetically isolated; intervention strategies must therefore be informed by a solid understanding of the implications on the genetic conservation of the species.

Finally, our results show inbreeding in all reproductive events of the population due mating among relatives originated probably from SGS. Such processes may have negative consequences for future generations due the inbreeding depression. In terms of seed collection for ex situ conservation, forest improvement, and environmental recovery, due to high levels of coancestry within fruits compared to between fruits, seeds should be collected from many fruits of each seed-tree to reduce the total coancestry and increase the variance effective size of the sample. We recommend that seeds must be collected from a minimum of 60 seed trees.

\section{Acknowledgments}

This study was supported by the Fundação de Amparo à Pesquisa do Estado da São Paulo (FAPESP; 2010/19613-4) and the Conselho Nacional de Desenvolvimento Científico e Tecnológico (CNPq; 473677/2010-5). The authors would like to thank FAPESP for financial support provided to ROM (scholarship $\mathrm{n}^{\circ}$ 2011/01518-8). A research fellowship for AMS was provided by Conselho Nacional de Desenvolvimento Científico e Tecnológico (CNPq/ Brazil). Finally, we thank Dr. Evelyn Nimmo for her editing of the manuscript.

\section{References}

Breed, M. F., M. H. K. Marklund, K. M. Ottewell, M. G. Gardner, J. B. C. Harris and A. J. Lowe (2012): Pollen diversity matters: revealing the neglected effect of pollen diversity on fitness in fragmented landscapes. Molecular Ecology 21: 5955-5968.

Carvalho, P. E. R. (2003): Espécies florestais brasileiras: recomendações silviculturais, potencialidades e uso da madeira. Colombo: EMBRAPA CNPF.

COCKERHAM, C. C. (1969): Variance of gene frequencies. Evolution 23: 72-84.

Degen, B. AND A. M. Sebbenn (2014): Genetic and tropical forest. In: PANCEL, L. and M. KöLH, editors. Tropical Forestry Handbook, $2^{\text {nd }}$ ed. Berlin Heidelberg: Springer Verlag; p. 1-30.
Doyle, J. J. and J. L. Doyle (1987): A rapid DNA isolation procedure for small quantities of fresh leaf tissue. Phytochemistry 19: 11-15.

Durigan, G. and J. C. B. Nogueira (1990): Recomposição de matas ciliares. Série Registros: Instituto Florestal de São Paulo 4: 1-14.

Eckert, C. G., S. Kalisz, M. A. Geber, R. Sargent, E. Elle, P-O. Cheptou, C. Goodwillie, M. O. Johnston, J. K. Kelly, D. A. Moeller, E. Porcher, R. H. Ree, M. Vallejo-Marín and A. A. WinN (2009): Plant mating system in a changing world. Trends in Ecology and Evolution 25: $35-43$.

Feres, J. M., A. M. Sebbenn, M. C. Guidugli, M. A., Mestriner, M. L. T. Moraes and A. L. AlzateMARIN (2012): Mating system parameters at hierarchical levels of fruits, individuals and populations in the Brazilian insect-pollinated tropical tree, Tabebuia roseo-alba (Bignoniaceae). Conservation Genetics 13: 393-405.

Fuchs, E. J., J. A. Lobo and M. Quesada (2003): Effects of forest fragmentation and flowering phonology on the reproductive success and mating patterns of the tropical dry forest tree Pachira quinata. Conservation Biology 17: 149-157.

Goodwillie, C., S. Kalisz and C. G. ECKERT (2005): The evolutionary enigma of mixed mating systems in plants: Occurrence, theoretical explanations, and empirical evidence. Annual Review in Ecology, Evolution and Systematic 36: 47-79.

GoudET, J. (2002): Fstat (Version 2.9.3.2.): a computer program to calculate F-statistics. Journal of Heredity 86: $485-486$.

HARDY, O. and X. VEKEMANS (2002): SPAGeDI: a versatile computer program to analyze spatial genetic structure at the individual or population levels. Molecular Ecology Notes 2: 618-620.

Hardy, O. J., L. Maggia, E. Bandou, P. Breyne, E. J. Caron, M. H. Chevallier, A. Doligez, C. Dutech, A. Kramer, C. Latouche-Halle, V. Troispoux, V. Veron and B. Degen (2006): Fine-scale genetic structure and gene dispersal inferences in 10 neotropical tree species. Molecular Ecology 15: 559-571.

Kamm, U., F. Gugerli, P. Rotach, P. Edwards and R. HoldEREGGER (2010): Open areas in a landscape enhance pollen-mediated gene flow of a tree species: evidence from northern Switzerland. Landscape Ecology 25: 903-911.

KöPPEN, W. (1948): Climatologia: con un estudio de los climas de la tierra. México: Fondo de Cultura Econômica.

Lacerda, E. B. L., M. Kanashiro and A. M. Sebbenn (2008): Long-pollen movement and deviation of random mating in a low-density continuous population of Hymenaea courbaril in the Brazilian Amazon. Forest Ecology and Management 40: 462470.

LiNDGREN, D., D. G. Luigi and P. A. JeFFERSON (1997): Status number for measuring genetic diversity. Forest Genetics 4: 69-76. 
Loiselle, B. A., V. L. Sork, J. NASON and C. GRAHAM (1995): Spatial genetic structure of a tropical understory shrub. Psychotria officinalis (Rubiaceae). American Journal of Botany 82: 1420-1425.

LORENZI, H. (2000): Árvores brasileiras: manual de identificação e cultivo de plantas nativas do Brasil. Nova Odessa: Intituto Plantarum.

Manoel, R. O., P. F. Alves, C. L. Dourado, A. P. S. C. Gaino, M. L. M. Freitas, M. L. T. Moraes and A. M. SEBbenN (2012): Contemporary pollen flow, mating patterns and effective population size inferred from paternity analysis in a small fragmented population of the Neotropical tree Copaifera langsdorffii Desf. (Leguminosae-Caesalpinioideae). Conservation Genetics 13: 613-623.

Manoel, R. O., M. L. M. Freitas, M. A. Barreto, M. L. T. Moraes and A. M. SEBbenN (2014): Development and characterization of 32 microsatellite loci in Genipa americana (Rubiaceae). Applied Plant Science 2: 1300084.

Manoel, R. O., M. L. M. Freitas, E. V. TAmbarussi, M. L. T. Moraes and A. M. Sebbenn (2015): Study of Mendelian inheritance, genetic linkage and genotypic disequilibrium at six microsatellite loci of Genipa americana L. (Rubiaceae). Genetic and Molecular Research 14: 8161-8169. .

Moraes, M. A., A. P. S. Gaino, M. L. T. Moraes, M. L. M. Freitas and A. M. Sebbenn (2012): Estimating coancestry within open-pollinated progenies of a dioecious species: the case study of Myracrodruon urundeuva. Silvae Genetica 61: 256-264.

MuraWASKI, D. A. and J. L. HAMrICK (1991): The effect of the density of flowering individuals on the mating systems of nine tropical tree species. Heredity 67: 167-174.

NEI, M. (1977): $F$-statistics and analysis of gene diversity in subdivided populations. Annals Human Genetics 41: 225-233.

Novaes, R. M. L., J. G. Rodrigues and M. B. Lovato (2009): An efficient protocol for tissue sampling and DNA isolation from the stem bark of Leguminosae trees. Genetics and Molecular Research 8: 86-96.

QuesadA, M., E. Fuchs and J. Lobo (2001): Pollen load size, reproductive success and progeny kinship of natural pollinated flowers of the tropical dry forest tree, Pachira quinta. American Journal of Botany 88: 2113-2118.

Quesada, M., Y. Herrerías-Diego, J. A. Lobo, G. Sánchez-Montoya, F. Rosas and R. Aguilar (2013): Long-term effects of habitat fragmentation on mating patterns and gene flow of a tropical dry forest tree, Ceiba aesculifolia (Malvaceae: Bombacoideae). American Journal of Botany 100: 10951101.

Ribeiro, M. C., J. P. Metzger, A. C. Martensen, F. J. Ponzoni and M. M. Hirota (2009): The Brazilian Atlantic Forest: how much is left, and how is the remaining forest distributed? Implications for conservation. Biological Conservation 142: 1141-1153.
RITLAND, K. (1989): Correlated matings in the partial selfer Mimulus guttatus. Evolution 43: 848-859.

RITLAND, K. (2002): Extensions of models for the estimation of mating systems using $\mathrm{n}$ independent loci. Heredity 88: 221-228.

SAMPSON, J. F. (1998): Multiple paternity in Eucalyptus rameliana (Myrtaceae). Heredity 81: 349-355.

SAS (1999): INSTITUTE INC. SAS procedures guide. Version 8 (TSMO). Cary, p 454.

SEBbENN, A. M. (2006): Sistema de reprodução em espécies arbóreas tropicais e suas implicações para a seleção de árvores matrizes para reflorestamentos ambientais. In: HigA, A. R. and L. D. Silva. Pomares de sementes de espécies florestais nativas. Curitiba: FUPEF, p. 93-138.

Sebbenn, A. M., P. Y. Kageyama and R. Vencovsky (1998): Variabilidade genética, sistema reprodutivo e estrutura genética especial em Genipa americana L. através de marcadores isoenzimáticos. Scientia Forestalis 53: 15-30.

Sebbenn, A. M., A. C. M. Carvalho, M. L. M. Freitas, S. M. B. Moraes, A. P. S. C. Gaino, J. M. Silva, C. Jolivet and M. L. T. Moraes (2011): Low level of realized seed and pollen gene flow and strong spatial genetic structure in a small, isolated and fragmented population of the tropical tree Copaifera langsdorffii Desf. Heredity 106: 134145.

Silva, C. R. S., P. S. B. Albuquerque, F. R. ErveDosa, J. W. S. Mota, A. Figueira and A. M. SEBBENN (2011): Understanding the genetic diversity, spatial genetic structure and mating system at the hierarchical levels of fruits and individuals of a continuous Theobroma cacao population from the Brazilian Amazon. Heredity 106: 973-985.

TAmaki, I., S. Setsuko and N. Tomaru (2009): Estimation of outcrossing rates at hierachical levels of fruits, individuals, populations and species in Magnolia stellata. Heredity 102: 381-388.

Tarazi, R., A. M. Sebbenn, P. Y. Kageyama and R. Vencovsky (2013): Edge effects enhance selfing and seed harvesting efforts in the insect-pollinated Neotropical tree Copaifera langsdorffii (Fabaceae). Heredity 110: 578-585.

Vieira, I. C. G., N. Galvão and N. A. RosA (1996): Caracterização morfológica de frutos e germinação de sementes de espécies arbóreas nativas da Amazônia. Boletin doMuseu Paraense Emílio Goeldi: Botanica 12: 271-288.

Ward, M., C. W. Dick, R. Gribel and A. J. Lowe (2005): To self, or not to self... A review of outcrossing and pollen-mediated gene flow in Neotropical trees. Heredity 95: 246-254.

White, G. M., D. H. Boshier and W. Powell (1999): Genetic variation within a fragmented population of Swietenia humilis Zucc. Molecular Ecology 8: 1899-1909. 